\title{
ANTIDIABETIC ACTIVITY OF BACOLEPIS NERVOSA (WIGHT AND ARN.) DECNE. EX MOQ. EXTRACT ON ALLOXAN INDUCED DIABETIC RATS
}

\author{
AROCKIA JENECIUS ALPHONSE A. ${ }^{1}$, MOHAN VR $^{2 *}$, DOSS A. ${ }^{3}$ \\ ${ }^{1}$ Department of Botany, St. Mary's College (Autonomous), Thoothukudi, Tamil Nadu, ${ }^{2}$ Ethnopharmacology Unit, Research Department of \\ Botany, V. O. Chidambaram College, Thoothukudi, Tamil Nadu, ${ }^{3}$ Department of Microbiology, Kamaraj College, Thoothukudi, Tamil Nadu \\ Email: vrmohanvoc@gmail.com
}

Received: 21 Aug 2016 Revised and Accepted: 21 Sep 2016

\begin{abstract}
Objective: The aim of this study was to investigate the effect of ethanol extracts of stem and leaf of Bacolepis nervosa as antihyperglycemic, antihyperlipidemic and antioxidant activity in alloxan-induced diabetic rats.

Methods: Diabetes was induced in wistar albino rats by administration of alloxan monohydrate $(150 \mathrm{mg} / \mathrm{kg})$. The ethanol extract of $B$. nervosa lea and stem at a dose of 150 and $300 \mathrm{mg} / \mathrm{kg}$ body weight was administrated at a single dose per day to diabetes-induced rats for a period of $14 \mathrm{~d}$. The effect of ethanol extract of $B$. nervosa leaf and stem on blood glucose, insulin, urea, creatinine, $\mathrm{HbA}_{1} \mathrm{C}$, serum protein, albumin, globulin, serum enzymes, serum lipid profiles, lipid peroxidase (LPO) and antioxidant enzymes like superoxide dismutase (SOD), catalase (CAT), glutathione peroxidase (GPx) and reduced glutathione (GSH) were measured in the diabetic rats.
\end{abstract}

Results: The ethanol extract of B. nervosa stem and leaf elicited significant reduction in blood glucose $(p<0.001)$, serum enzymes (SGPT, SGOT, ALP) $(p<0.01)$, lipid parameters (TC, TG, VLDL-LDL, PL) $(p<0.01)$ except HDL-C and significantly increased insulin $(p<0.01), \mathrm{HDL}-\mathrm{C}(p<0.05)$, , GPx, GSH, SOD and CAT $(p<0.05)$ at the dose of $300 \mathrm{mg} / \mathrm{kg}$ when compared with the diabetic-induced control.

Conclusion: From the above results, it is concluded that ethanol extracts of $B$. nervosa leaf and stem possesses significant antihyperglycemic, antihyperlipidemic and antioxidant effect in alloxan induced diabetic rats.

Keywords: Antidiabetic activity, Bacolepis nervosa, Alloxan, Serum lipid profile, Antioxidant enzyme

(C) 2016 The Authors. Published by Innovare Academic Sciences Pvt Ltd. This is an open access article under the CC BY license (http://creativecommons.org/licenses/by/4. 0/) DOI: http://dx.doi.org/10.22159/ijpps.2016v8i11.14803

\section{INTRODUCTION}

Diabetes mellitus is a complex and a multifarious group of disorders that disturbs the metabolism of carbohydrates, fat and protein. It results from shortage or lack of insulin secretion or reduced sensitivity of the tissue to insulin [1]. This deficiency in insulin results in Type 1 diabetes or insulin dependent diabetes mellitus. Type 2 diabetes or non-insulin dependent diabetes mellitus is a result of hyperglycemia caused by overproduction of glucose at the hepatic level or because of abnormal $\beta$ cell function or insulin resistance at target cells [2].

Diabetes mellitus is the sixth leading cause of death globally [3] According to World Health Organization, the number of diabetes cases in Southern Asia and Western Pacific are currently 171 million and it is expected to reach about 336 million by the end of 2030 (Sunil et al., 2011). According to the International Diabetes Federation, about 366 million people around the world had diabetes in 2011 and the number was predicted to double by the year 2030 [4].

Diabetes also gives rise to various secondary problems such as retinopathy, peripheral vascular insufficiencies, and neuropathy. These secondary problems take place due to the oxidative stress and DNA damage caused by the generation of free radicals in the cells [5]. Currently available synthetic antidiabetic agents produce serious side effects like hypoglycemic coma [6]) and hepatorenal disturbances [7]. Moreover, they are not safe during pregnancy [8] Diabetes is still not completely curable by the present antidiabetic agents. Insulin therapy is the only satisfactory approach in diabetes mellitus, even though it has several drawbacks like insulin resistance, anorexia, brain atrophy and fatty liver in chronic treatment [9].

Diabetes mellitus is a disorder of carbohydrate metabolism in which sugars in the body are not oxidized to produce energy due to the lack of the pancreatic hormone insulin. Alloxan is the most commonly employed agent for the induction of experimental diabetic animal models of human insulin dependent diabetes mellitus. There is an increasing evidence that alloxan caused diabetes by rapid depletion of cells by DNA alkylation and accumulation of cytotoxic free radicals that is suggested to result from initial islet inflammation, followed by infiltration of activated macrophages and lymphocyte in the inflammatory focus. It leads to a reduction in insulin release thereby a drastic reduction in plasma insulin concentration leading to stable hyperglycemic states [10].

Alternative strategies to the current modern pharmacotherapy of diabetes mellitus are urgently needed [11], because of the inability of existing modern therapies to control all the pathological aspects of the disorder, as well as the enormous cost and poor availability of the modern therapies for many rural populations in developing countries. Traditionally, a number of plants have been used in various herbal preparations in the management of diabetes and only a few of them have been proven scientifically [12]. Bacolepis nervosa (Wight and Arn.) Decne. ex Moq. (Periplocaceae) is an endemic plant to Nilgiri Biosphere Reserve, Western Ghats, Tamil Nadu, India. This plant contains a rich source of bioactive compounds such as phenolic compounds, flavonoids, steroids and alkaloids. The impact of this plant in various disease treatments should be considered to discover new drug molecule or its derived compounds. But no such literature are revealed for its activity against treatment for diabetes. Hence the present study focuses on evaluating the antidiabetic activity of stem and leaf extracts of Bacolepis nervosa.

\section{MATERIALS AND METHODS}

Chemicals and reagents

ELISA kit was purchased from Aura Biotechnologies Pvt. Ltd., Chennai. Insulin was obtained from Jain Diagnostic Pvt. Ltd., New Delhi. Dinitrophenylhydrazine (DNPH) reagent was purchased from Sigma-Aldrich (India). Standard pellet diet was obtained from 
Goldmohar brand, Hindustan Lever Ltd., Mumbai, India. All other chemicals and reagents used in this study were analytical grade.

\section{Plant material}

The whole plant of Bacolepis nervosa (Wight and Arn.) Decne. ex Moq. was collected from Kothagiri, Nilagiri Biosphere Reserve, Western Ghats, Tamil Nadu and identified by the Botanical Survey of India, Coimbatore. A voucher specimen (specimen number VOCB6413) was retained in Ethnopharmacology Unit, Research Department of Botany, V. O. Chidambaram College, Tuticorin for further reference.

\section{Preparation of plant extract}

The stem and leaves of the plant were dried under shade and then powdered separately with a mechanical grinder to obtain a coarse powder, which was then subjected to extraction in a Soxhlet apparatus using ethanol. The ethanol extract was concentrated in a rotary evaporator. The concentrated ethanol extract was used for preliminary phytochemical screening [13] and antidiabetic activity.

\section{Animals}

Normal healthy male wistar albino rats $(180-240 \mathrm{~g})$ were housed under standard environmental conditions at a temperature $(25 \pm 2$ ${ }^{\circ} \mathrm{C}$ ) and light and dark (12:12h). Rats were fed with standard pellet diet (Goldmohur brand, Ms Hindusthan lever Ltd., Mumbai, India) and water ad libitum. The study was carried out as per IAEC approval no. 1012/C06/CPSEA-Corres-2008-2009.

\section{Acute toxicity studies}

An acute oral toxicity study was performed as per OECD-423 guidelines (acute toxic class method), albino rats $(n=6)$ of either sex selected by random sampling were used for acute toxicity study [14]. The animals were kept fasting for overnight and provided only with water, after that the extracts were administered orally at $5 \mathrm{mg} / \mathrm{kg}$ body weight by gastric intubations and observed for $14 \mathrm{~d}$. If mortality was observed in two out of three animals, then the dose administered was assigned as a toxic dose. If mortality was observed in one animal, then the same dose was repeated again to confirm the toxic dose. If mortality was not observed, the procedure was repeated for higher doses such as 50, 100 up to $2000 \mathrm{mg} / \mathrm{kg}$ body weight.

\section{Experimental induction of diabetes in rats}

Three months old male Wistar albino rats weighing 180-240 g were obtained from the animal house of the laboratory of Agricultural University, Trissur, Kerala. All animals were kept in an environmentally controlled room with $12 \mathrm{~h}$ light/12 h dark cycle. The animals had free access to water and standard rat diet. The rats were injected with alloxan monohydrate dissolved in sterile normal saline at a dose of 150 and $300 \mathrm{mg} / \mathrm{kg}$ body weight, intraperitoneally. Since alloxan is capable of producing fatal hypoglycemia as a result of massive pancreatic insulin release, rats were treated with $20 \%$ glucose solution intraperitoneally after $6 \mathrm{~h}$. The rats were then kept for the next $24 \mathrm{~h}$ on $5 \%$ glucose solution bottles in their cages to prevent hypoglycemia [15]. After a fortnight, rats with moderate diabetes having glycosuria (indicated by Benedict's test for urine) and hyperglycemia with blood glucose range of $200-260 \mathrm{mg} / 100 \mathrm{ml}$ were used for the experiment.

\section{Experimental design}

In the present investigation, non-diabetic control rats and diabeticinduced rats were used. Diabetic was induced in rats two weeks before starting the treatment. The rats were divided into the following seven groups after the induction of diabetics. Each group consists of 6 rats.

Group-I: Rats received normal saline daily for $14 \mathrm{~d}$, orally by using an intragastric catheter tube (IGC) and served as normal control.

Group-II: Diabetic rats received normal saline daily for $14 \mathrm{~d}$, orally by using an IGC, at a dose of $2.5 \mathrm{ml} / \mathrm{kg}$ body weight and served as diabetic induced control.

Group-III: Diabetic rats received ethanol stem extract of B. nervosa at the dose of $150 \mathrm{mg} / \mathrm{kg}$ body weight daily for $14 \mathrm{~d}$, orally by using an IGC.
Group-IV: Diabetic rats received ethanol stem extract of $B$. nervosa at the dose of $300 \mathrm{mg} / \mathrm{kg}$ body weight daily for $14 \mathrm{~d}$, orally by using an IGC.

Group-V: Diabetic rats received ethanol leaf extract of B. nervosa at the dose of $150 \mathrm{mg} / \mathrm{kg}$ body weight daily for $14 \mathrm{~d}$, orally by using an IGC.

Group-VI: Diabetic rats received ethanol leaf extract of B. nervosa at the dose of $300 \mathrm{mg} / \mathrm{kg}$ body weight daily for $14 \mathrm{~d}$, orally by using an IGC.

Group-VII: Diabetic rats received glibenclamide $(600 \mu \mathrm{g} / \mathrm{kg}$ body weight) for $14 \mathrm{~d}$, orally by using an IGC.

The plant drug treatments were given between 9.30 to $10.00 \mathrm{~h}$ in the morning. All the rats were sacrificed on the morning of the respective experimental day by decapitation. Blood was collected, sera separated by centrifugation at $3000 \mathrm{rpm}$ for $10 \mathrm{~min}$ and stored at- $20^{\circ} \mathrm{C}$ until used for enzyme and biochemical assays.

\section{Biochemical analysis}

The animals were sacrificed at the end of the experimental period of $14 \mathrm{~d}$ by decapitation. Blood was collected, sera separated by centrifugation at $3000 \mathrm{~g}$ for $10 \mathrm{~min}$. Serum glucose was measured by the 0-toluidine method [16]. Insulin level was assayed by EnzymeLinked Immunosorbent Assay (ELISA) kit [17]. Glycosylated hemoglobin (HbA1C) estimation was carried out by a modified colorimetric method of [18]. Serum total cholesterol (TC) [19], total triglycerides (TG) [20], low-density lipoprotein cholesterol (LDL-C), very low-density lipoprotein chloesterol (VLDL-C) [21] and highdensity lipoprotein cholesterol (HDL-C) [22] were analyzed. Serum protein [23] and serum albumins were determined by the quantitative colorimetrically method by using bromocresol green. The total protein minus the albumin gives the globulin, serum glutamate pyruvate transaminase (SGPT) and serum glutamate oxaloacetate transaminase (SGOT) was measured spectrophotometrically by utilizing the method of [24], Serum alkaline phosphatase (ALP) was measured by the method of [25]. Lipid peroxidation (LPO) [26], reduced glutathione (GSH) [27], glutathione peroxidase (GPx) [28], Catalase (CAT) [29] and superoxide dismutase (SOD) [30] in serum, liver and kidney were analyzed in the normal, diabetic induced and drug treated rats.

\section{Statistical analysis}

The data were analyzed using student's t-test statistical methods. For the statistical tests $p$ values of less than 0.01 and 0.05 was taken as significant.

\section{RESULTS}

\section{Phytochemical screening}

The distribution of different phytochemical constituents in petroleum ether, benzene, ethyl acetate, methanol and ethanol extracts of stem and leaf powder of $B$. nervosa were evaluated qualitatively. The presence of alkaloid, anthraquinone, catechin, coumarin, flavonoid, phenol, quinone, saponin, steroid, tannin, terpenoid, sugar, glycoside and xanthoprotein have been confirmed in the methanol and ethanol extracts of stem and leaf of B. nervosa.

\section{Effect of stem and leaf extracts of $B$. nervosa on body weight}

In the antidiabetic activity, the effect of $B$. nervosa stem and leaf extracts on body weight is measured on $14^{\text {th }}$ day of post induction and was compared with normal and diabetic control groups. The values are shown in table 1 . Alloxan induced diabetic rats showed a decrease in body weight compared to normal rats. Oral administration of stem extract at the dose of $300 \mathrm{mg} / \mathrm{kg}$ showed an increase in body weight on $14^{\text {th }}$ day of post induction when compared to other drug treated diabetic rats.

\section{Effect of stem and leaf extracts of $B$. nervosa on fasting glucose level}

A marked rise in fasting blood glucose level was observed in diabetic control group (Group II) as compared with normal control rats (Group I). Stem and leaf extracts of $B$. nervosa $(150$ and $300 \mathrm{mg} / \mathrm{kg})$ exhibited a dose-dependent significant $(p<0.05)$ antihyperglycemic activity on $0,7^{\text {th }}$ and $14^{\text {th }}$ day post treatment. The antihyperglycemic 
effect of stem extract (Group III and IV) was found to be more effective than leaf extract (Group V and VI). The reference standard, glibenclamide showed a significant $(p<0.001)$ reduction in blood glucose compared to diabetic control (table 1).

\section{Effect of stem and leaf extracts of $B$. nervosa on serum profile}

The effect of stem and leaf extracts of B. nervosa on the serum insulin, glucose, urea, creatinine and glycolyted $\mathrm{Hb}$ of normal and diabetic treated rats are shown in table 2 . The results revealed that the insulin level was significantly $(p<0.001)$ reduced in diabetic rats (Group II) compared to normal rats (Group I) but the other biochemical parameters like glucose, urea, creatinine and glycolyted $\mathrm{Hb}$ were significantly $(p<0.01 ; p<0.001)$ increased in diabetic rats than control rats. A significant $(p<0.05 ; p<0.01)$ increase in insulin level and a decrease in other biochemical parameters mentioned above were observed in the stem and leaf extracts of $B$. nervosa treated diabetic rats (Groups III-VI).

Effect of stem and leaf extracts of $B$. nervosa on protein and liver marker enzyme

The levels of total protein, albumin, globulin and liver marker enzymes such as SGPT, SGOT and ALP in the serum of diabetic rats are presented in table 3. When compared with normal control rats (Group I), the diabetic control rats (Group II) had decreased levels of total serum protein, albumin, globulin and elevated levels of liver marker enzymes such as SGPT, SGOT and ALP. After treatment with the stem and leaf ethanol extracts of B. nervosa at 150 and $300 \mathrm{mg} / \mathrm{kg}$ body weight doses (Groups III, IV, V and VI) and glibenclamide (Group VII), the total protein, albumin, globulin and liver marker enzymes were brought back to near normal levels. It was further evident that stem extract $(300 \mathrm{mg} / \mathrm{kg}$ body weight) treated rats showed significant $(P<0.01)$ reduction of liver marker enzyme when compared to diabetic control and other treated groups.

\section{Effect of stem and leaf extracts of $B$. nervosa on serum lipid profile}

Table 4 illustrates the effect of stem and leaf extracts of $B$. nervosa on the levels of total cholesterol (TC), triglycerides (TG), HDL-C, LDL-C and VLDL-C in the serum of experimentally induced diabetic rats. It is evident from the results that the serum levels of total cholesterol (TC), triglycerides (TG), very low density lipoproteins (VLDL-C) and low density lipoproteins (LDL-C) were significantly increased $(p<0.01)$ whereas, serum high density lipoproteins (HDL-C) level was significantly reduced $(p<0.05)$ in diabetic rats compared to normal control group. It was further evident that stem and leaf extracts treated groups significantly $(p<0.05 ; p<0.01)$ reduced the levels of TC, TG, VLDL-C, and LDL-C whereas significantly $(p<0.05)$ increased HDL-C respectively in a dose-dependent manner (table 4).

Effect of stem and leaf extracts of $B$. nervosa on antioxidant enzymes

Alloxan induced diabetic rats were found to have decreased SOD, GSH, GPx and CAT enzyme in serum, liver and kidney as compared with control. Administration of stem and leaf extracts to the diabetic rats resulted in significant $((p<0.05 ; p<0.01)$ increase in the activities of SOD, GSH, GPx and CAT (tables 5-7). Diabetic rats were found to exhibit significant $(p<0.01 ; p<0.001)$ increase of lipid peroxidase in serum, liver and kidney compared to control rats. Treatment with stem and leaf extracts produced significant $(p<0.05)$ decrease in LPO.

Table 1: Effect of stem (BNS) and leaf extracts (BNL) of Bacolepis nervosa on the body weight and fasting blood glucose in normal, diabetic and diabetic treated rats

\begin{tabular}{|c|c|c|c|c|c|c|}
\hline \multirow[t]{2}{*}{ Group } & \multirow{2}{*}{$\begin{array}{l}\text { Mean initial body } \\
\text { weight (g) }\end{array}$} & \multirow{2}{*}{$\begin{array}{l}\text { Mean final body } \\
\text { weight }(\mathrm{g})\end{array}$} & \multirow{2}{*}{ 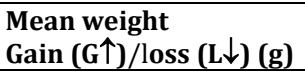 } & \multicolumn{3}{|c|}{ Fasting Blood glucose (mg/dl) } \\
\hline & & & & 0-Day & 7-days after & 14-days after \\
\hline $\mathrm{I}$ & $224.65 \pm 8.14$ & $239.88 \pm 1.65$ & $15.23 \uparrow$ & $63.91 \pm 2.51$ & $72.65 \pm 1.93$ & $70.44 \pm 1.34$ \\
\hline II & $216.54 \pm 7.22$ & $201.68 \pm 7.13$ & $14.86 \downarrow$ & $194.88 \pm 6.54^{* *}$ & $204.54 \pm 5.13^{* * *}$ & $216.62 \pm 5.26^{* * *}$ \\
\hline III & $214.90 \pm 7.60$ & $220.55 \pm 9.15$ & 5.65 & $208.22 \pm 7.45$ & $182.24 \pm 6.15^{*} \mathrm{~ns}$ & $138.22 \pm 5.46^{\mathrm{nsa}}$ \\
\hline IV & $198.54 \pm 6.24$ & $216.19 \pm 8.16$ & $17.65 \uparrow$ & $228.11 \pm 4.93^{* *}$ & $161.54 \pm 3.41^{* a a}$ & $126.22 \pm 3.54^{\text {nsa }}$ \\
\hline V & $204.15 \pm 4.80$ & $209.40 \pm 5.10$ & 5.25 & $204.11 \pm 7.80$ & $192.15 \pm 6.40^{*} \mathrm{~ns}$ & $170.65 \pm 6.85^{* * n s}$ \\
\hline VI & $219.63 \pm 8.13$ & $214.50 \pm 8.16$ & 5.13 & $216.16 \pm 8.13^{* *}$ & $186.16 \pm 4.55^{* a}$ & $156.16 \pm 4.93^{* a}$ \\
\hline VII & $214.54 \pm 6.16$ & $219.43 \pm 5.81$ & $4.89 \uparrow$ & $218.65 \pm 6.94^{* * *}$ & $101.24 \pm 6.11^{\text {aaa }}$ & $82.93 \pm 3.16^{\text {aаa }}$ \\
\hline
\end{tabular}

Values are expressed as mean \pm SEM, $\mathrm{n}=6$ in each group, ${ }^{*} p<0.05 ;{ }^{* * *} p<0.01 ;{ }^{* * *} p<0.001$-Comparison made between normal control, diabetic and drug treated, a $p<0.05$; ${ }^{\text {aa }} p<0.01$ aaa $p<0.001$-Comparison made between diabetic control and drug-treated groups, ns-not significant.

Table 2: Effect of stem (BNS) and leaf extracts (BNL) of Bacolepis nervosa on the serum insulin, glucose, urea, creatinine and HbAlc level of normal, diabetic and diabetic treated rats

\begin{tabular}{lllll}
\hline Group & Insulin (MIu/ml) & Glucose $(\mathbf{m g} / \mathbf{d l})$ & Urea $(\mathbf{m g} / \mathbf{d l})$ & Creatinine $(\mathbf{m g} / \mathbf{d l})$ \\
\hline I & $15.62 \pm 1.24$ & $70.44 \pm 1.34$ & $16.84 \pm 0.92$ & $0.73 \pm 0.06$ \\
II & $4.39 \pm 0.36^{* * *}$ & $216.62 \pm 5.26^{* * *}$ & $41.68 \pm 1.36^{* *}$ & $3.08 \pm 0.54^{*}$ \\
III & $10.04 \pm 0.18^{\mathrm{a}}$ & $138.22 \pm 5.46^{\text {nsa }}$ & $22.15 \pm 1.48^{\mathrm{a}}$ & $1.34 \pm 0.18^{\mathrm{a}}$ \\
IV & $10.93 \pm 0.78^{\text {aa }}$ & $126.22 \pm 3.54^{\text {nsa }}$ & $19.65 \pm 0.96^{\text {nsa }}$ & $1.26 \pm 0.16^{\text {aa }}$ \\
V & $7.96 \pm 0.53^{* *}$ & $170.65 \pm 6.85^{* * \text { ns }}$ & $34.15 \pm 1.13^{*}$ & $2.16 \pm 0.65^{*}$ \\
VI & $9.62 \pm 0.91^{\mathrm{a}}$ & $156.16 \pm 4.93^{* \mathrm{a}}$ & $32.68 \pm 1.54^{*}$ & $1.84 \pm 0.23^{\text {ns }}$ \\
VII & $16.39 \pm 1.24^{\text {aaa }}$ & $82.93 \pm 3.16^{\text {aaa }}$ & $17.23 \pm 0.86^{\text {aa }}$ & $1.04 \pm 0.06^{\text {aa }}$ \\
\hline
\end{tabular}

Values are expressed as mean $\pm \mathrm{SEM}, \mathrm{n}=6$ in each group, ${ }^{*} p<0.05{ }^{* *} p<0.01 ; p^{* * * *}<0.001$-Comparison made between normal control to diabetic control and drug treated groups, ${ }^{a} p<0.05$; ${ }^{\text {aa }} p<0.01$; aaa $p<0.001$-Comparison made between diabetic control and drug treated groups; ns-not significant

Table 3: Effect of stem (BNS) and leaf extracts (BNL) of Bacolepis nervosa on the serum protein, albumin, globulin, SGOT, SGPT and ALP level of normal, diabetic induced and drug treated rats

\begin{tabular}{|c|c|c|c|c|c|c|}
\hline Group & Protein (g/dl) & Albumin (g/dl) & Globulin (g/dl) & SGPT (U/l) & SGOT (U/l) & ALP (U/l) \\
\hline $\mathrm{I}$ & $8.23 \pm 0.54$ & $4.68 \pm 0.11$ & $3.55 \pm 0.13$ & $13.54 \pm 0.98$ & $19.92 \pm 1.04$ & $163.59 \pm 6.23$ \\
\hline II & $6.92 \pm 0.16^{*}$ & $4.16 \pm 0.31^{\mathrm{ns}}$ & $2.76 \pm 0.17^{*}$ & $52.62 \pm 2.41^{* * *}$ & $48.68 \pm 2.11^{* * *}$ & $296.54 \pm 6.74^{* * *}$ \\
\hline III & $7.34 \pm 0.18$ & $4.51 \pm 0.22$ & $2.83 \pm 0.19$ & $23.18 \pm 0.94^{\text {aа }}$ & $24.13 \pm 1.34^{\mathrm{a}}$ & $196.22 \pm 4.16^{\mathrm{aa}}$ \\
\hline IV & $8.07 \pm 0.13$ & $4.39 \pm 0.34$ & $3.68 \pm 0.18$ & $19.55 \pm 1.42^{\text {aа }}$ & $18.54 \pm 1.88^{\text {aа }}$ & $182.61 \pm 4.82^{\text {aa }}$ \\
\hline V & $6.98 \pm 0.74^{*}$ & $4.31 \pm 0.11$ & $2.67 \pm 0.11$ & $31.54 \pm 1.31^{\mathrm{a}}$ & $32.90 \pm 1.28^{* *}$ & $198.23 \pm 4.15^{*}$ \\
\hline VI & $7.14 \pm 0.25$ & $4.54 \pm 0.13$ & $2.60 \pm 0.15$ & $21.65 \pm 1.68^{\text {nsa }}$ & $29.33 \pm 1.93^{*}$ & $192.67 \pm 5.86^{* a}$ \\
\hline VII & $8.19 \pm 0.26$ & $4.62 \pm 0.62$ & $3.57 \pm 0.14$ & $14.88 \pm 0.98^{\mathrm{aa}}$ & $17.29 \pm 0.96^{\mathrm{aa}}$ & $158.73 \pm 3.92^{\text {aа }}$ \\
\hline
\end{tabular}

Values are expressed as mean \pm SEM, $\mathrm{n}=6$ in each group, ${ }^{*} p<0.05 ;{ }^{* *} p<0.01 ; p^{* * *}<0.001$-Comparison made between normal control to diabetic control and drug treated groups, a $p<0.05$, aa $p<0.01$-Comparison made between diabetic control and drug treated groups; ns-not significant 
Table 4: Effect of stem (BNS) and leaf extracts (BNL) of Bacolepis nervosa on the serum lipid profile of normal, diabetic induced and drug treated rats

\begin{tabular}{|c|c|c|c|c|c|c|}
\hline Group & TC (mg/dl) & TG(mg/dl) & HDL-C (mg/dl) & VLDL (mg/dl) & LDL (mg/dl) & PL (mg/dl) \\
\hline I & $131.65 \pm 2.84$ & $123.54 \pm 1.69$ & $38.17 \pm 1.16$ & $24.70 \pm 0.34$ & $68.78 \pm 1.46$ & $185.16 \pm 2.67$ \\
\hline II & $192.11 \pm 4.36^{* *}$ & $179.56 \pm 5.64^{* *}$ & $24.16 \pm 5.84^{*}$ & $35.91 \pm 0.57^{*}$ & $132.04 \pm 2.78^{* *}$ & $238.97 \pm 3.95^{* * *}$ \\
\hline III & $139.15 \pm 2.16^{\mathrm{a}}$ & $107.22 \pm 1.04^{\text {aа }}$ & $30.16 \pm 1.27^{\mathrm{ns}}$ & $21.44 \pm 0.13^{a}$ & $87.55 \pm 1.13^{\mathrm{a}}$ & $191.84 \pm 2.86^{\mathrm{ns}}$ \\
\hline IV & $133.18 \pm 1.93^{\mathrm{a}}$ & $118.16 \pm 1.63^{\text {aа }}$ & $36.93 \pm 1.16^{\mathrm{a}}$ & $23.63 \pm 0.49^{a}$ & $72.62 \pm 1.66^{\mathrm{aa}}$ & $186.53 \pm 3.16^{\mathrm{a}}$ \\
\hline V & $158.28 \pm 4.04^{\mathrm{ns}}$ & $139.26 \pm 3.16^{\mathrm{a}}$ & $28.16 \pm 3.16^{\mathrm{ns}}$ & $27.85 \pm 1.13^{\mathrm{ns}}$ & $102.27 \pm 1.58^{\mathrm{ns}}$ & $208.87 \pm 4.16^{\mathrm{ns}}$ \\
\hline VI & $143.54 \pm 3.81^{\mathrm{a}}$ & $128.67 \pm 1.93^{\mathrm{a}}$ & $31.65 \pm 1.84^{\mathrm{ns}}$ & $25.73 \pm 0.88^{\mathrm{ns}}$ & $86.16 \pm 1.26^{\mathrm{a}}$ & $195.75 \pm 3.13^{\mathrm{ns}}$ \\
\hline VII & $126.63 \pm 2.56^{\text {aa }}$ & $132.66 \pm 1.46^{\text {aa }}$ & $39.23 \pm 1.04^{\mathrm{a}}$ & $26.53 \pm 0.74^{\mathrm{a}}$ & $60.87 \pm 1.68^{\text {aа }}$ & $180.70 \pm 2.65^{a}$ \\
\hline
\end{tabular}

Values are expressed as mean \pm SEM, $\mathrm{n}=6$ in each group, ${ }^{*} p<0.05^{* *} p<0.01$; ${ }^{* * *} p<0.001$ Comparison made between normal control to diabetic control and drug-treated groups, ${ }^{\mathrm{a}} p<0.05$; aa $p<0.01$ Comparison made between diabetic control to drug treated groups; ns not significant

Table 5: Effect of stem (BNS) and leaf extracts (BNL) of Bacolepis nervosa on serum LPO, GP, GSH, SOD and CAT in the normal, diabetic and drug treated rats

\begin{tabular}{|c|c|c|c|c|c|}
\hline \multirow[t]{2}{*}{ Groups } & \multicolumn{5}{|l|}{ Parameters } \\
\hline & LPO (nanomol/mg protein) & $\mathrm{GP}_{\mathrm{x}}(\mathrm{u} / \mathrm{mg}$ protein $)$ & GSH (u/mg protein) & SOD (u/mg protein) & CAT (u/mg protein) \\
\hline I & $2.16 \pm 0.031$ & $694.16 \pm 7.51$ & $36.84 \pm 0.91$ & $492.16 \pm 11.15$ & $96.39 \pm 2.16$ \\
\hline II & $4.63 \pm 0.024^{* *}$ & $312.18 \pm 4.86^{* * *}$ & $9.16 \pm 0.11^{* * *}$ & $263.81 \pm 7.91^{* * *}$ & $42.63 \pm 1.84^{* *}$ \\
\hline III & $2.43 \pm 0.018^{\mathrm{a}}$ & $483.15 \pm 6.18^{* a}$ & $20.22 \pm 1.53$ & $401.22 \pm 5.16^{\mathrm{aa}}$ & $89.29 \pm 1.27^{a}$ \\
\hline IV & $2.21 \pm 0.054^{\mathrm{a}}$ & $506.84 \pm 3.62^{\mathrm{a}}$ & $24.62 \pm 1.84^{\mathrm{a}}$ & $426.13 \pm 5.62^{\mathrm{a}}$ & $94.67 \pm 2.05^{a}$ \\
\hline V & $2.96 \pm 0.012^{\mathrm{ns}}$ & $481.13 \pm 3.84^{* n s}$ & $17.16 \pm 1.15^{\mathrm{a}}$ & $373.15 \pm 6.15^{* * a}$ & $73.16 \pm 1.25^{a}$ \\
\hline VI & $2.69 \pm 0.073^{\mathrm{ns}}$ & $496.16 \pm 5.41^{* a}$ & $19.22 \pm 1.26^{\mathrm{ns}}$ & $398.65 \pm 6.84^{* a}$ & $86.54 \pm 1.36^{\mathrm{a}}$ \\
\hline VII & $1.64 \pm 0.051^{\text {aa }}$ & $721.56 \pm 8.42^{\text {aа }}$ & $31.62 \pm 1.86^{\mathrm{aa}}$ & $489.26 \pm 6.92^{\text {aа }}$ & $101.16 \pm 2.16^{\mathrm{aa}}$ \\
\hline
\end{tabular}

Values are expressed as mean \pm SEM, $\mathrm{n}=6$ in each group, ${ }^{*} p<0.05 ;{ }^{* *} p<0.01,{ }^{* * * *} p<0.001$ comparisons made between normal control to diabetic control and drug-treated groups, a $p<0.05$; aa $p<0.01$ comparison made between diabetic rats and drug treated; ns: not significant

Table 6: Effect of stem (BNS) and leaf extracts (BNL) of Bacolepis nervosa on Liver LPO, GPx, GSH, SOD and CAT in the normal, diabetic and drug treated rats

\begin{tabular}{|c|c|c|c|c|c|}
\hline \multirow{2}{*}{ Group } & \multicolumn{5}{|l|}{ Parameters } \\
\hline & LPO (nanomol/mg protein) & GPX $(u / m g$ protein) & GSH (u/mg protein) & SOD (u/mg protein) & CAT (u/mg protein) \\
\hline I & $0.108 \pm 0.024$ & $58.16 \pm 1.84$ & $38.84 \pm 1.26$ & $21.65 \pm 0.88$ & $14.92 \pm 0.92$ \\
\hline II & $0.438 \pm 0.067^{* * *}$ & $24.86 \pm 1.52^{* * *}$ & $20.19 \pm 0.98^{*}$ & $9.29 \pm 0.69^{* *}$ & $3.84 \pm 0.13^{* * *}$ \\
\hline III & $0.268 \pm 0.027^{* a}$ & $40.16 \pm 1.22^{\mathrm{ns}}$ & $30.18 \pm 1.04^{\mathrm{ns}}$ & $16.18 \pm 0.77^{\mathrm{ns}}$ & $9.36 \pm 0.13^{a}$ \\
\hline IV & $0.184 \pm 0.062^{\mathrm{a}}$ & $49.83 \pm 1.81^{\text {aa }}$ & $36.18 \pm 1.08^{\mathrm{a}}$ & $19.86 \pm 0.98^{a}$ & $10.13 \pm 0.18^{\text {aa }}$ \\
\hline V & $0.268 \pm 0.046^{* *}$ & $37.16 \pm 1.23^{\mathrm{ns}}$ & $26.13 \pm 0.75^{\mathrm{ns}}$ & $11.34 \pm 0.78$ & $7.26 \pm 0.18^{\mathrm{ns}}$ \\
\hline VI & $0.204 \pm 0.051^{\mathrm{nsa}}$ & $43.92 \pm 1.84^{\mathrm{a}}$ & $31.26 \pm 1.21^{\mathrm{ns}}$ & $15.81 \pm 0.82^{\mathrm{ns}}$ & $9.16 \pm 0.26^{\mathrm{a}}$ \\
\hline VII & $0.113 \pm 0.056^{\mathrm{aa}}$ & $61.84 \pm 1.64^{\text {aа }}$ & $36.89 \pm 1.92^{\mathrm{a}}$ & $23.92 \pm 1.05^{\text {aа }}$ & $12.46 \pm 0.21^{\text {aa }}$ \\
\hline
\end{tabular}

Values are expressed as mean \pm SEM, $\mathrm{n}=6$ in each group, ${ }^{*} p<0.05 ;{ }^{* *} p<0.01 ;{ }^{* * *} p<0.001$ comparisons made between normal control to diabetic control and drug-treated groups, ${ }^{a} p<0.05$; ${ }^{\text {aa }} p<0.01$ comparison made between diabetic rats and drug treated; ns: not significant

Table 7: Effect of stem (BNS) and leaf extracts (BNL) of Bacolepis nervosa on Kidney LPO, GP ${ }_{x}$, GSH, SOD and CAT in the normal, diabetic and drug treated rats

\begin{tabular}{llllll}
\hline Group & Parameters & & & & \\
\cline { 2 - 6 } & LPO (nanomol/mg protein) & GPx $(\mathbf{u} / \mathbf{m g}$ protein) & GSH (u/mg protein) & SOD (u/mg protein) & CAT (u/mg protein) \\
\hline I & $0.059 \pm 0.026$ & $8.14 \pm 0.74$ & $34.28 \pm 1.34$ & $18.34 \pm 1.13$ & $40.84 \pm 1.36$ \\
II & $0.192 \pm 0.012^{* * *}$ & $4.13 \pm 0.54^{* *}$ & $11.93 \pm 1.16^{*}$ & $7.86 \pm 0.93^{*}$ & $16.93 \pm 0.94^{* *}$ \\
III & $0.112 \pm 0.034^{* a}$ & $7.04 \pm 0.18^{\text {ns }}$ & $22.16 \pm 0.93^{*}$ & $10.91 \pm 0.17$ & $31.15 \pm 1.16$ \\
IV & $0.094 \pm 0.014^{\mathrm{a}}$ & $7.39 \pm 0.17^{\mathrm{a}}$ & $28.63 \pm 1.54^{\mathrm{aa}}$ & $14.92 \pm 0.13^{\mathrm{a}}$ & $36.23 \pm 1.18^{\mathrm{a}}$ \\
V & $0.123 \pm 0.021^{* *}$ & $5.13 \pm 0.14^{\mathrm{ns}}$ & $20.16 \pm 0.93^{*}$ & $10.23 \pm 0.11$ & $24.16 \pm 0.78^{*}$ \\
VI & $0.102 \pm 0.013^{\text {ns }}$ & $6.94 \pm 0.13$ & $24.93 \pm 1.65^{\text {nsa }}$ & $13.64 \pm 0.15^{\text {ns }}$ & $30.55 \pm 1.30^{\mathrm{a}}$ \\
VII & $0.068 \pm 0.019^{\text {aa }}$ & $7.96 \pm 0.021^{\mathrm{a}}$ & $29.33 \pm 1.16^{\text {aa }}$ & $21.63 \pm 0.87^{\mathrm{aa}}$ & $39.13 \pm 1.64^{\mathrm{aa}}$ \\
\hline
\end{tabular}

Values are expressed as mean \pm SEM, $\mathrm{n}=6$ in each group, ${ }^{*} p<0.05 ;{ }^{* * *} p<0.01 ;{ }^{* * *} p<0.001$ comparisons made between normal control to diabetic control and drug-treated groups, a $p<0.05$; aa $p<0.01$ comparison made between diabetic rats and drug treated; ns: not significant

\section{DISCUSSION}

Diabetes mellitus is a heterogeneous metabolic disorder that has affected substantial population regardless of sex, age and socioeconomic status [31]. The primary complications of diabetes include damage to the eyes, kidneys, and nerves. Damage to the eyes, known as diabetic retinopathy, is caused by damage to the blood vessels in the retina of the eye and can result in gradual vision loss and potentially blindness. Damage to the kidneys, known as diabetic nephropathy, can lead to tissue scarring, urine protein loss and eventually chronic kidney disease, sometimes requiring dialysis or kidney transplant.

Damage to the nerves of the body, known as diabetic neuropathy, is the most common complication of diabetes. The prevention of diabetes is an urgent worldwide health concern. Medicinal plants could be considered as a potential source for providing a reasonable amount of the required elements other than diet to the patients of diabetes mellitus [32]. 
In the present study, there was a weight loss in the alloxan induced diabetic rats, whereas treatment with ethanol extracts of stem and leaf of $B$. nervosa at both the doses showed improvement in their body weight indicating that the plant extracts had beneficial effects in preventing loss of body weight of diabetic rats. The probable mechanism of this benefit is due to its effects in controlling muscle wasting (i.e.) by reversal antagonism [33].

In this present investigation, the effect of stem and leaf ethanol extracts of $B$. nervosa has been evaluated for its antidiabetic and antihyperlipidemic potential. Alloxan is a potent diabetogen that is reduced to dialuric acid which is then auto-oxidized back to alloxan resulting in the production of $\mathrm{H}_{2} \mathrm{O}_{2}, \mathrm{O}_{2}, \mathrm{O}^{2}$-and hydroxyl radicals and causes damages to the beta cells of islets of langerhans [34]. This causes a profound decrease in insulin level and consequent increase in fasting blood glucose level in diabetic control animals (Group II). Administration of test drug for $14 \mathrm{~d}$ (Group III, IV, V and VI) was found to regenerate the pancreatic beta-cells which results in the normal secretion of insulin. Insulin, the potent hypoglycemic hormone thereby reduces the blood glucose level significantly $(p<0.05)$.

Glycosylated haemoglobin has been found to be increased over a long period of time in diabetes. During diabetes, the excess of glucose present in the blood reacts with hemoglobin to form glycosylated haemoglobin [35]. The rate of glycation is proportional to the concentration of blood glucose [36]. In the present study, the diabetic rats had shown higher levels of HbA1c compared to those in normal rats. Treatments with stem and leaf ethanol extracts of B. nervosa and glibenclamide showed a significant decrease in HbA1c levels in diabetic rats that could be due to an improvement in glycemic status.

A significant $(p<0.01)$ elevation in serum constituents, urea and creatinine were observed in alloxan induced diabetic rats (Group II) when compared to control rats. The ethanol extracts of stem and leaf of $B$. nervosa were administered orally to rats for fourteen days, and these extracts reversed the levels of urea and creatinine to near normal. Administration with glibenclamide also decreased the levels of urea and creatinine to some extent. It confirms the protection of vital tissues (Kidney and liver) including the pancreas, thereby reducing the causation of diabetes in the experimental animals.

The hypoglycemic activity of ethanol extract of Butea monosperma leaves was found to induce insulin release from pancreatic cells of diabetic rats [37]. Ahmed et al. [38] reported the ethyl acetate soluble fraction of an absolute ethanol extract of Pterocarpus marsupium, which significantly lowered blood sugar level with a corresponding increase in insulin level in alloxan-induced diabetic rats. It is evident from this study that there is an increase in insulin level in diabetic rats treated with stem and leaf extracts of $B$. nervosa. Many plants have showed their hypoglycemic and insulin release stimulatory effects [39-43]. Grover et al. [44] have reported 45 medicinal plants and their products that have been used in the Indian traditional system of medicine and shown experimental or clinical antidiabetic activity. The most effective and commonly used antidiabetic plants are Allium cepa, A. sativum, Aloe vera, Gymnema sylvestre, Syzygium cumini, Ficus benghalensis, Rubia cordifolia and Tinospora cordifolia [44-46].

It is very clear from the results presented in table-3, a significant $(p<0.05)$ reduction in serum protein, albumin and globulin were observed in alloxan induced diabetic control rats (Group-II), when compared to normal control (Group-I) and glibenclamide-treated rats (Group-VII). Protein, albumin, and globulin levels were found to be restored to normal with the administration of stem and leaf ethanol extracts of $B$. nervosa to the diabetic rats. These results were in accordance with the effect of Eugenia singampattiana and Polygala rosmarinifolia in diabetic [47-48]. The increased levels of serum protein, albumin and globulin in alloxan induced diabetic rats are presumed to be due to increased protein catabolism and gluconeogenesis during diabetes [49].

Elevation of serum biomarker enzymes such as SGOT, SGPT and ALP was observed in alloxan induced diabetic rats indicating impaired liver function, which is obviously due to hepatocellular necrosis. Treatment with ethanol extracts of $B$. nervosa and glibenclamide resulted in a decrease of transaminase activities in alloxan-treated animals. In this study, it was observed that levels of ALP, SGPT and SGOT in alloxan induced diabetic rats were elevated. It may be due to leaking out of enzymes from the tissues and migrating into the circulation by the adverse effect of alloxan [50]. Diabetic complications such as increased gluconeogenesis and ketogenesis may be due to elevated transaminase activities. SGOT and SGPT levels are indicators of liver function. Hence restoration of normal levels indicates the normal function of liver [51].

The levels of serum lipid profiles, total cholesterol (TC), triglycerides (TG), HDL-C, LDL-C, VLDL-C, PL and LDL/HDL in control and experimental rats were investigated in the present study. When compared to normal rats, the alloxan-induced diabetic rats showed a significant $(p<0.01)$ increase in serum lipid profiles except HDL-C, which was in decreased level in the diabetic rats than normal rats. The diabetic rats treated with ethanol extracts of stem and leaf of $B$. nervosa and glibenclamide showed a significant $(p<0.05 ; p<0.01)$ decrease in the content of lipid profiles comparing to diabetic control rats. Similarly, HDL-C level increased in plant extract treated rats when compared to diabetic rats. The impairment of insulin secretion results in the enhanced metabolism of lipids from the adipose tissue to the plasma. A variety of derangements in metabolic and regulatory mechanisms due to insulin deficiency are responsible for the observed accumulation of lipids [52]. Further, it has been reported that diabetic rats treated with insulin showed normalized lipid levels [53]. Diabetic rats treated with B. nervosa stem and leaf extracts and glibenclamide also showed normalized lipid levels. Thus, the results indicate that stem and leaf extracts of $B$. nervosa may also possess insulin-like action by virtue of the ability to lower the lipid levels. These results are similar to earlier reports observed with the other plants $[48,54]$. The present study reveals that the levels of serum lipid profiles are usually raised in diabetic rats, and such an elevation represents a risk factor for coronary heart diseases [55]. Lowering the serum lipid level through dietary or drug therapy seems to be associated with a decrease in the risk of cardiovascular disease [56].

During diabetes, there is an enhanced activity of the enzyme resulting in an increased lipolysis releasing more fatty acids into the circulation [57]. The increased fatty acid concentration also increases the $\beta$-oxidation of fatty acids, producing more acetyl Co-A and cholesterol during diabetes. In normal condition, insulin increases receptor-mediator removal of LDL-cholesterol and decreased the activity of insulin, during diabetes, causes hypercholesterolemia. Hypercholesterolemia and hyperglycemia have been reported to occur in diabetic rats [55]. The increased concentration of free fatty acid may be due to lipid breakdown, and this may cause increased generation of NADPH-dependent microsomal lipid peroxidation. Phospholipids are increased in alloxan induced diabetic rats. Phospholipids are present in cell membrane and make up the vast majority of the surface lipoprotein forming a lipid bilayer that acts as an interface with both polar plasma environment and non-polar lipoprotein of lipoprotein core [58]. Increased phospholipids level in tissues was reported by Venkateswaran et al. [59] and Pari and Satheesh [60] in streptozotocin-induced diabetic rats. Administration with the stem and leaf ethanol extracts of $B$. nervosa and glibenclamide decreased the level of phospholipids.

The results of the present study showed increased lipid peroxidation (LPO) on serum, liver and kidney of alloxan-induced diabetic rats. Earlier studies have confirmed that there is an increased lipid peroxidation in liver, kidney, and brain of diabetic rats [61-62]. Lipid peroxidation is a normal phenomenon involved in a peroxidative loss in unsaturated lipids, thus bringing about lipid degradation and membrane disorganization. Peroxidized lipid has been considered to play a significant role in the pathogenesis of several diseases and may be taken as a molecular mechanism of cell injury under pathological conditions.

In the present study, an increase in the levels of LPO was found, and these levels were significantly $(p<0.05 ; p<0.01)$ reduced after the supplementation with the ethanol extracts of stem and leaf of $B$. nervosa and glibenclamide. This indicates that stem and leaf extracts of $B$. nervosa inhibit oxidative damage due to the antiperoxidative 
effect of ingredients present in them. This could be correlated with the previous studies of Pari and Latha [63] on Cassia auriculata flower, Prince and Menon [64] and Prince et al. [65] on Syzigium cuminii, Prince et al. [66] on Tinospora cordifolia and Latha and Pari [67] on Scoparia dulcis indicating antiperoxidative and antihyperlipidemic effects in diabetic animals. Apart from the regulation of carbohydrate metabolism, insulin also plays an important role in the lipid metabolism. Insulin is a potent inhibitor of lipolysis since it inhibits the activity of hormone-sensitive lipase in adipose tissue and suppresses the release of free fatty acids [68].

The levels of superoxide dismutase (SOD), catalase (CAT), glutathione peroxide (GPx) and reduced glutathione (GSH) in the serum, liver and kidney of the control and experimental rats were studied. A highly significant reduction in the activity of scavenging mitochondrial enzymes is observed in alloxan induced rats. These adverse changes could be reversed to near normal with the treatment of stem and leaf ethanol extracts of $B$. nervosa and glibenclamide. The results were in accordance with the effect of Polygala rosmarinifolia [69].

The antioxidant enzymes SOD and CAT play an important role in reducing cellular stress, SOD scavenges the superoxide radical by converting it to hydrogen peroxide and molecular oxygen [70] while CAT brings about the reduction of hydrogen peroxides and protects higher tissues from the highly reactive hydroxyl radicals [71]. In the present investigation both these enzymes registered low levels of activity in diabetic controls indicating diabetes induces stress. Such a decline in these enzyme activities has been reported earlier [72]. When stem and leaf extracts of $B$. nervosa are administrated to the diabetic rats, it improved both SOD and CAT activities, reflecting the antioxidant potency of plant extract. The present study indicates the reduction in the ability of SOD, CAT, GPx and GSH in alloxan induced diabetic rats (Group II). These results reveal the protective role of this plant extracts in decreasing lipid peroxidation by the normalizing antioxidant system.

\section{CONCLUSION}

The present study revealed that B. nervosa stem and leaf extracts had an antihyperglycemic, hypolipidemic and antioxidant agent. The bioactive components responsible for the observed activities are not precisely known, but it may be one or more of the phytochemical constituents established to be present in the stem and leaf extracts. In the present study, phytochemical screening reported that the presence of flavonoid in the stem and leaf extracts might be the constituents responsible for these activities.

\section{CONFLICT OF INTERESTS}

Declared none

\section{REFERENCES}

1. Prasad SK, Kulshreshtha A, Qureshi TN. Antidiabetic activity of some herbal plants in streptozotocin-induced diabetic albino rats. Pak J Nutr 2009;8:551-7.

2. Fajans SS, Cloutier MC, Crowther RL. Clinical and etiological heterogeneity of idiopathic diabetes mellitus (Banting Memeoral Lecture). Diabetes 1997;7:1112-25.

3. Nash D, Koenig J, Novielli K, Liberoni R, Reisman M. The importance of the individualized pharmaceutical therapy in the treatment of diabetes mellitus. Dis Manage 2001;4:5-23.

4. IDF, Diabetes Atlas. 5th ed. 166 Chaussee da la Hulpe B-1170 Brussels, Belgium. Available from www.idf.org/diabetesatlas/ 5e/the-global-burden). [Last Accessed on 5 May 2013].

5. Carvalho LFP, Samadder AN, Agarwal A, Fernandes LFC, Abrao MS. Oxidative stress biomarkers in patients with endometriosis: a systematic review. Arch Gynecol Obstet 2012;286:1033-40.

6. Davis SN. Insulin, Oral hypoglycemic agent and the Pharmacology of endocrine Pancreas. In: Goodman and Gillman's The Pharmacological Basis of Therapeutics. Laurence L. Burnton, John S. Lazo, Keith L. Parker. Eds. 11 ${ }^{\text {th }}$ Edn. McGraw-Hill Medical Publishing Division, New York; 2006. p. 1613-41.

7. Suba V, Murugesan T, Arunachalam G, Mandal SC, Sahu BP. Antidiabetic potential of Barleria lupilina extract in rats. Phytomedicine 2004;11:202-5.
8. Rahman Q, Zaman K. Medicinal plants with hypoglycemic activity. J Ethnopharmacol 1989;26:1-55.

9. Piedrola G, Novo E, Escober F, Garcia-Robles R. White blood cell count and insulin resistance in patients with coronary artery disease. Annu Endocrinol 2001;62:7-10.

10. Szkudelski T. The mechanism of alloxan and streptozotocin action in B cells of the rat pancreas. Physiol Res 2001;50:537-46.

11. WHO. WHO launches the first global strategy on traditional medicine: Press release WHO; 2002. p. 38.

12. Jia Q, Liu X, Wu X, Wang R, Hu X, Li Y, et al. Hypoglycemic activity of a polyphenolic oligomer-rich extract of Cinnamomum parthenoxylon bark in normal and streptozotocin-induced diabetic rats. Phytomedicine 2009;16:744-50.

13. Brinda P, Sasikala P, Purushothaman KK. Pharmacognostic studies on Merugan kizhangu. Bull Med Ethnobot Res 1981;3:84-96.

14. OECD. Organisation for Economic Co-operation and Development (OECD), Guidelines for the testing of chemicals/ section 4: Health Effects Test No: 423; Acute Oral ToxicityAcute Toxic Class Method. OECD. Paris; 2002.

15. Dhandapani S, Ramasamy SV, Rajagopal S, Namasivayam N. Hypolipidaemic effect of Cuminum cyminum L. on alloxaninduced diabetic rats. Pharmacol Res 2002;46:251-5.

16. Sasaki T, Matsuy S, Sanae A. Effect of acetic acid concentration on the colour reaction in the 0 -toluidine boric acid method for blood glucose determination. Rinsho Kagaku 1972;1:346-50.

17. Anderson L, Dinesen B, Jorgonsen PN, Poulsen F, Roder MF. Enzyme immune assay for intact human insulin in serum or plasma. Clin Chem 1993;38:578-82.

18. Karunanayake EH, Chandrasekharan NV. An evaluation of a colorimetric procedure for the estimation of glycosylated haemoglobin and establishment of reference values for Sri Lanka. J Natl Sci Counc Sri Lanka 1985;13:235-58.

19. Parekh AC, Jung. Cholesterol determination with ferric acetate, uranium acetate and sulphuric acid, ferrous sulphate reagent. Anal Chem 1970;112:1423-27.

20. Rice EW. Triglycerides in serum In: Standard Methods in Clinical Chemistry, (Ed) Roderick MP, Academic Press: New York; 1970. p. 215-22.

21. Friedwald WT, Levy RI, Fredrickson DS. Estimation of the concentration of low-density lipoprotein cholesterol in plasma, without use of the preparative ultracentrifuge. Clin Chem 1972;18:499-504.

22. Warnick GR, Nguyan T, Albers AA. Comparison of improved precipitation methods for quantification of high-density lipoprotein cholesterol. Clin Chem 1985;31:217-22.

23. Lowry $\mathrm{OH}$, Rosenbrough NJ, Farr AL, Randall RJ. Protein measurement with the Folin's phenol reagent. J Biol Chem 1951;193:265-75.

24. Reitman S, Frankel SA. a Colorimetric method for the determination of serum glutamic oxaloacetic and glutamic pyruvic transaminases. Am J Clin Pathol 1957;28:56-63.

25. King EJ, Armstrong AR. Determination of serum and bile phosphatase activity. Can Med Assoc J 1934;31:56-63.

26. Rehman SU. Lead induced regional lipid peroxidation in the brain. Toxicol Lett 1984;21:333-7.

27. Prins HK, Loos JA. In Glutathione, biochemical methods in red cell genetics, edited by J. J. Yunis. Academic Press: New York; 1969. p. 127-9.

28. Paglia DE, Valentine WN. Studies on the quantitative and qualitative characterization of erythrocyte glutathione peroxidase. J Lab Clin Med 1967;70:158-69.

29. Bergmeyer HU, Grassl M, Walter HE. Methods of Enzymatic Analysis Vol. Volume II. Verlag Chemie, Deerfield Beach, FL; 1983.

30. Madesh M, Balasubramanian KA. Microtiter plate assays for superoxide dismutase using MTT reduction by superoxide. Indian J Biochem Biophys 1998;35:184-8.

31. Kannur DM, Hukkeri VI, Akki KS. Antidiabetic activity of Caesalpinia bonducella seed extracts in rats. Fitoter 2006;77:546-9.

32. Subbiah R, Kasiappan R, Karuran S, Sorimuthu S. Beneficial effects of Aloe vera leaf gel extract on lipid profile status in rats with streptozotocin diabetes. Clin Exp Pharmacol Physiol 2006;33:232-7. 
33. Whitton PD, Hens DA. Glycogen synthesis in perfused liver of streptozotocin diabetic rats. Biochem J 1975;150:153-65.

34. Vijayvargia R, Kumar M, Gupta S. Effect of Enicostemma littorale Blume on alloxan-induced diabetes mellitus in rats. Indian J Exp Biol 2000;38:781-4.

35. Alyassin D, Ibrahim KA. Minor hemoglobin fraction and level of fasting blood glucose. J Fac Med Unive Baghdad 1981;23:373-80.

36. Ragini N, Prasad KVSRG, Bharathi K. Antidiabetic and antioxidant activity of Shorea tumbuggnia Rox. Int J Innovation Pharm Res 2011;2:113-21.

37. Sharma N, Garg V. Antidiabetic and antioxidant potential of ethanolic extract of Butea monosperma leaves in alloxan-induced diabetic mice. Indian J Biochem Biophys 2009;46:99-105.

38. Ahmed F, Khalid P, Khan MM, Meena C, Rastogi AK, Kidwai JR. Hypoglycemic activity of Pterocarpus marsupium wood. J Ethnopharmacol 1991;35:71-5.

39. Ajay SS. Hypoglycemic activity of Coccinia indica (Cucurbitaceae) leaves. Int J PharmTech Res 2009;1:892-3.

40. Kumar RS, Hemalatha S. In vitro antioxidant activity of alcoholic leaf extract and subfractions of Alangium lamarckii Thwaites. J Chem Pharm Res 2011;3:259-67.

41. Ohadoma SC, Michael HU. Effects of co-administration of methanol leaf extract of Catharanthus roseus on the hypoglycemic activity of metformin and glibenclamide in rats. Asian Pac J Trop Med 2011;4:475-7.

42. Ravi K, Ramachandran B, Subramanian S. Effect of Eugenia jambolana seed kernel on antioxidant defense system in streptozotocin-induced diabetes in rats. Life Sci 2004;75:2717-31.

43. Thirumalai T, Therasa VS, Elumalai EK, David E. Hypoglycemic effect of Brassica juncea (seeds) on a streptozotocin-induced diabetic male albino rat. Asian Pac J Trop Biomed 2011;4:323-5.

44. Grover JK, Yadav S, Vats V. Medicinal plants of India with antidiabetic potential. J Ethnopharmacol 2002;81:81-100.

45. Mohana Rao GM, Rao CV, Pushpangadan P, Shirwaikar A. Hepatoprotective effects of rubiadin, a major constituent of Rubia cordifolia Linn. J Ethnopharmacol 2005;30:1-7.

46. Ziyyat A, Legssyer A, Mekhfi H. Phytotherapy of hypertension and diabetes in oriental Morocco. J Ethnopharmacol 1997;58:45-54.

47. Kala SMJ, Tresina PS, Mohan VR. The antioxidant, antihyperlipidaemic and antidiabetic activity of Eugenia singampattiana Bedd. leaves in alloxan induced diabetic rats. Int J Pharm Pharm Sci 2012;4:412-6.

48. Alagammal M, Paulpriya K, Mohan VR. Evaluation of antiinflammatory activity of ethanol extract of Polygala javana DC. whole plant. Int Res J Pharm 2012;3:212-3.

49. Palanivel R, Thangavel M, Selvendran K, Sakthisekaran D. Insulinomimetric effect of ammonium paratungstate on protein metabolism in streptozotocin-induced diabetic rats. Biomedical 2001;21:23-30.

50. Stanley P, Prince M, Menon VP. Hypoglycemic and other related actions of Tinospora cordifolia roots in alloxan induced diabetic rats. J Ethnopharmacol 1999;70:9-15.

51. Ghosh S, Suryawanshi SA. Effect of Vinca rosea extract in the treatment of alloxan diabetes in male albino rats. Indian. J Exp Biol 2001;39:748-59.

52. Rajalingam R, Srinivasan N, Govindarajulu P. Effect of alloxan iduced diabetes on lipid profiles in renal cortex and medulla of mature albino rats. Indian J Exp Biol 1993;31:577-9.

53. Pathak RM, Ansai S, Mahmood A. Changes in chemical composition of intertional brush border membrane in alloxan induced chronic diabetes. Indian J Exp Biol 1981;19:503-5.

54. Maruthupandian A, Mohan VR, Sampathraj. The antidiabetic, anti-hyperlipidaemic and antioxidant activity of Wattakaka volubilis (L. F) Stapf. leaves in alloxan induced diabetic rats. Int J Pharm Sci Res 2010;1:83-90.
55. Mironova MA, Klein RL, Virella GL, Lopes-Virella MF. Antimodified LDL antibodies, LDL-containing immune complexes and susceptibility of LDL to in vitro oxidation in patients with type-2 diabetes. Diabetes 2000;49:1033-49.

56. Scott M, Grundy. Diabetis cardiovas. Dis Circ 1999;100:113446.

57. Agarth CD, Bjorgell P, Nilson EP. The effect of tolbutamide on lipoproteins and lipoproteinlipase and hormone-sensitive lipase. Diabetes Res Clin Pract 1999;46:99-108.

58. Cohn RM, Roth KS. Lipid and lipoprotein metabolism In: Biochemistry and Diseases, Williams and Willkins publishers, Baltimore; 1996. p. 280.

59. Venkateswaran S, Pari L, Saravanan G. Effect of Phaseolus vulgaris on circulatory antioxidants and lipids in streptozotocin-induced diabetic rats. J Med Food 2002;5:97104.

60. Pari L, Satheesh AM. Antidiabetic effect of Boerhavia diffusa: effect on serum and tissue lipids in experimental diabetes. J Med Food 2004;7:472-6

61. Latha M, Pari L. Preventive effects of Cassia auriculata L. flowers on brain lipid peroxidation in rats treated with streptozotocin. Mol Cell Biochem 2003a;243:23-8.

62. Ananthan R, Latha M, Ramkumar KM, Pari L, Basker L, Narmatha Bai V. Antidiabetic effect of Gymnema montanum leaves Effect on lipid peroxidation induced oxidative stress in experimental diabetes. Nutrition 2004;6:379-86.

63. Pari L, Latha M. Effect of Cassia auriculata flowers on blood sugar levels, serum and tissue lipids in streptozotocin diabetic rats. Singapore Med J 2002;43:617-21.

64. Prince PSM, Menon VP. Effect of Syzigium cumini in plasma antioxidants on alloxan-induced diabetes in rats. J Clin Biochem Nutr 1998;25:81-6.

65. Prince PSM, Kamalakkannan N, Menon VP. Antidiabetic and antihyperlipidaemic effect of alcoholic Syzigium cumini seeds in alloxan induced diabetic albino rats. J Ethnopharmacol 2004;91:209-13.

66. Prince PSM, Menon VP, Gunasekaran G. Hypolipidaemic action on Tinospora cordifolia root extract in alloxan diabetic rats. J Ethnophamacol 1999;14:4-16.

67. Latha M, Pari L. Modulatory effect of Scoparia dulcis in oxidative stress-induced lipid peroxidation in streptozotocin diabetic rats. J Med Food 2003b;6:379-86.

68. Loci AS, Shaabha M, Khazraji AL, Hussain A, Twaija A. Hypoglycemic effect of a valuable extract of Artemisia herbaalba II. Effect of a valuable extract on some blood parameters in diabetic animals. J Ethnopharmacol 1994;43:167-71.

69. Nishanthini A, Mohan VR. Antioxidant activity of Polygala rosmarinifolia Wight and Arn. The whole plant in alloxan induced diabetic rats. Int Res J Pharm 2012;3:223-5.

70. Robinson $\mathrm{BH}$. The role of manganese superoxide dismutase in health and disease. J Inherited Metab Dis 1998;21:598-603.

71. Brioukhanov AL, Netrusov AI. Catalase and superoxide dismutase: distribution, properties, and physiological role in cells of strict anaerobes. Biochem 2004;69:949-62.

72. Shanmugasundaram R, Kalpana Devi V, Tresina Soris $P$, Maruthupandian A, Mohan VR. Anti-diabetic, antihyperlipidaemic and antioxidant activity of Senna auriculata (L.) Roxb. leaves in alloxan induced diabetic rats. Int J PharmTech Res 2011;3:747-56.

\section{How to cite this article}

- Arockia Jenecius Alphonse A, Mohan VR, Doss A. Antidiabetic activity of Bacolepis nervosa (wight and arn.) decne. ex moq. extract on alloxan induced diabetic rats. Int J Pharm Pharm Sci 2016;8(11):320-326. 